\title{
KONSEP ALTRUISME DALAM PERSPEKTIF AJARAN AGAMA ISLAM (ITSAR)
}

\author{
Fina Hidayati, MA. \\ f.guidance@yahoo.com \\ Fakultas Psikologi \\ Universitas Islam Negeri (UIN) Maulana Malik Ibrahim malang
}

\begin{abstract}
Abstrak - Permasalahan moral yang tumbuh dalam pribadi manusia adanya tarikan permanen antara upaya pemenuhan kepentingan diri pribadi (egoistic) dengan tuntutan untuk kesediaan dirinya memerhatikan kepentingan orang lain (altruistic). Moral altruism memiliki sandaran kuat dari doktrin semua agama, terutama agama Islam. Dalam Islam juga mengenal istilah alitsar (at-tafdhil) suatu konsep perilaku sosial yang memberikan perlakuan kepada orang lain seperti perlakuan kepada dirinya sendiri. Banyaknya kajian Islam yang menjelaskan tentang pemikiran khoirunnas anfauhum linnas, maka penulis tertarik dengan penelitian yang berjudul tentang konsep altruisme dalam perspektif ajaran agama Islam yang biasa disebut dengan itsar. Metode penelitian yang digunakan adalah kualitatif dengan Pendekatan grounded theory. Hasil penelitian menunjukkan bahwa itsar adalah sikap dan tingkah laku utama yang mampu dilakukan oleh manusia yang telah mampu dan tidak hanya bersimpati dan berempati terhadap orang lain, tetapi mampu juga berkorban dan memberikan sesuatu yang bernilai bagi orang lain meskipun dirinya juga sedang memerlukan semata-mata hanya karena Allah SWT.
\end{abstract}

Kata Kunci: Altruisme dan Itsar

\section{PENDAHULUAN}

Permasalahan moral yang tumbuh dalam pribadi manusia adanya tarikan permanen antara upaya pemenuhan kepentingan diri pribadi (egoistic) dengan tuntutan untuk kesediaan dirinya memerhatikan kepentingan orang lain (altruistic). Setiap individu cenderung mendahulukan kepentingan dirinya sendiri sebelum mengurus kebutuhan orang lain, namun tuntutan batiniahnya juga ada dorongan untuk membantu kesulitan orang lain. Dalam kajian filsafat moral muncul perbedaan pandangan mengenai bawaan watak primordial manusia: antara egois versus altruis (Soroglou, 2013).

Kata "egois, egoistic dan egoisme" sering muncul dalam perbincangan ilmiah dan pergaulan. Sebaliknya "altruis, altruistic, altruisme" masih jarang dikaji. Sepanjang penelaahan penulis, istilah tersebut belum banyak dibahas secara spesifik dalam literature Islam di Indonesia sebagaimana model pengembangan teoritik di Barat (Effendi, 1995). Lingkup pembahasan akhlak oleh etikawan Muslim belum merambah pada keluasan tema altuistik.
Tetapi, dari sumber teks agama Islam dan perjalanan Rasulullah dapat ditemukan adanya imperatif yang ditafsirkan ke arah moral altruism. Terminology qurban, ihsan, infaq dan shadaqah merupakan rincian bentuk-bentul indicator yang dapat ditarik pada altruism (Abubakar \& Bamualim, 2006).

Jika dilacak sumber tekstualnya, moral altruism memiliki sandaran kuat dari doktrin semua agama yang memberikan porsi besar dalam pelayanan social (Sachdev, 2006). Dalam ajaran Islam kisah Nabi banyak menceritakan mengenai perjuanganNya untuk membela Ummat manusia sampai diakhir hayat. Prinsip yang demikian juga Nampak di generasi awal Islam yang oleh Al-Qur'an digambarkan mereka mengalahkan kepentingan pribadi mereka meskipun mereka sendiri dalam keadaan bersusah payah. Sikap yang demikian disebut dengan itsar 'ala al-nafs mengabaikan kepentingan pribadi, dan memperjuangkan kesejahteraan orang lain (Al Usmaini, 2002). Dalam Islam juga mengenal istilah al-itsar (at-tafdhil) suatu konsep perilaku sosial yang memberikan perlakuan kepada orang lain seperti 
perlakuan kepada dirinya sendiri (Munawwir, 1997). Perilaku itsar oleh al Jurjani, diposisikan sebagai puncak dari perilaku prososial (ukhuwah), mengingat bahwa tindakan lahiriyah itsar memiliki dimensi bathiniyah yang sangat komplek (As Syamali, 2007, Maktabah Syamilah). Kepribadian itsar memiliki akar dan landasan yang kuat dalam Islam. Itsar selain mengandung keutamaan secara psikologis, dan social, juga memiliki keutamaan spiritual. Itsar menjadi salah satu indikasi kesempurnaan iman dana mal (kewajiban) bagi seorang muslim.

Seperti yang dikemukakan oleh Sachdev (2006; Moroney, 2014) yang menyatakan Jika dilacak sumber tekstualnya, moral altruism memiliki sandaran kuat dari doktrin semua agama yang memberikan porsi besar dalam pelayanan social, dan banyaknya kajian Islam yang menjelaskan tentang pemikiran khoirunnas anfauhum linnas, maka penulis tertarik dengan penelitian yang berjudul tentang konsep altruisme dalam perspektif ajaran agama Islam yang biasa disebut dengan itsar.

\section{KERANGKA KERJA TEORITIK}

\section{Altruisme}

Altruism adalah tindakan suka rela yang dilkukan oleh seseorang ataupun kelompok orang untuk menolong orang lain tanpa mengharapkan imbalan apapun, kecuali mungkin perasaan telah melakukan perbuatan baik (Sears dkk, 1994). Menurut Myers, altruistic didefinisikan sebagai hasrat untuk menolong orang lain tanpa memikirkan kepentingan sendiri (Sarwono, 1999). Menurut Keer dkk. (2004) altruistic merupakan suatu sifat suka mempertahankan juga mengutamakan kepentingan orang lain, cinta kasih yang tidak terbatas pada sesama manusia, juga merupakan sifat manusia yang berupa dorongan untuk berbuat jasa dan kebaikan terhadap orang lain. Untuk mengukur seseorang tersebut dikatakan bersikap altruistic (Durkheim, 1997), digunakan indikator sebagai berikut: menolong sesama tanpa pamrih, tidak egois, bersedia berkorban, peka dan siap bertindak demi membantu sesama yang kesusahan, mempunyai rasa belas kasihan, murah hati, tidak tegaan, penuh kasih sayang, dan empati. Terdapat tiga makna yang dapat mewakili dari kata altruisme, yaitu:

a. Loving other as oneself, mencintai orang lain seperti diri sendiri

b. Behavior that promotes the survival chances of other at a cost to ones own, tingkah laku itu mempromosikan mempertahankan kehidupan harapan orang lain berharga untuk diri sendiri.

c. Self-sacrifice for the benefit of others, pengorbanan diri untuk kebaikan orang lain (Sachdev, 2006)

\section{Itsar}

Itsar adalah mendahulukan orang lain dari pada dirinya sendiri (al Usaimin, 2002). Seseorang disebut telah berpribadi itsar dalam kehidupan sehari-hari apabila telah mampu memandang kebutuhan dan kepentingan orang lain lebih penting dari pada kepentingan pribadinya sendiri (Al Usaimin, 2002). Al-itsar juga bisa diartikan sebagai suatu konsep perilaku sosial yang memberikan perlakuan kepada orang lain seperti perlakuan kepada dirinya sendiri (kamus al-Munawwir, 1997). Secara garis besar, pengertian itsar menurut ketiga ulama tersebut adalah "tindakan mendahulukan orang lain atas dirinya sendiri dalam hal keduniaan dengan sukarela karena semata mengharapkan akhirat" (Sholeh, 2011).

Al jurjani (dalam Sholeh, 2011) menambahkan kata kunci sekaligus memberi konteks yang jelas terhadap itsar yaitu, itsar sebagai 'puncak ukhuwah'. Berdasarkan kata kunci ini maka dapat dipahami bahwa tindakan itsar tidak muncul secara tiba

tiba. Itsar tumbuh seiring tumbuhnya rasa persaudaraan, ukhuwwah, melalui pendidikan, latihan dan pembiasaan seiring pertumbuhan usia seseorang. Maka dapat dikatakan bahwa pribadi mu'tsir, yang memiliki itsar, dapat tumbuh dengan baik jika dilandasi tumbuhnya kondisi mental yang sehat, empatik, mampu dan percaya kepada diri dan orang lain. Dengan landasan ini seseorang mampu menjalin hubungan yang tulus, dan berkomunikasi dengan jujur, serta membangun persaudaraan yang dekat dengan orang lain. Sebab hanya dengan kondisi psikologis dan tingkat pemahaman tersebut seseorang mampu mencapai puncak persaudaraan yaitu itsar, yang ditandai dengan kerelaan bekerja sama, menolong dan berkorban untuk orang lain dengan tulus tanpa mengharapkan imbalan dari sesama, tetapi meniatkan dengan ikhlas hanya untuk Allah SWT.

\section{METODE}

Pendekatan penelitian menggunakan grounded theory. Pendekatan ini bisa dilakukan dengan berpijak pada pendekatan prosedur sistematis yang memanfaatkan kausalitas, konsekuensi, coding selektif, dan sebagainya dari fenomena yang diteliti 
atau prosedur konstruktivis yang memanfaatkan pengumpulan data dengan cara memoing terhadap pandangan, keyakinan, nilai, atau ideology dari para partisipan (Nasution, 2007).

Penggalian data primer berupa teks-teks karya tulis yang berkaitan dengan Altruisme dan itsar. Sedangkan data sekunder berasal dari hasil wawancara dengan subyek penelitian yang diambil dari tehnik purposive sampling. Hal ini dikarenakan subyek penelitian harus memiliki karakteristik yang sesuai dengan keahlian dibidangnya. Subyek yang dipilih ada 5 , terdiri dari tokoh agama, tokoh masyarakat dan akademisi. Tehnik pengumpulan data yang digunakan adalah observasi, interview dan dokumentasi, yang nantinya hasil pengumpulan data tersebut akan dikumpulkan, kemudian mengorganisasikan yang dilanjutkan pengelompokan berdasarkan kategori, tema dan pola jawaban sehingga nantinya dapat dianalisis serta dapat diperoleh hasil penelitian ini.

Adapun keabsahan dan keajegan penelitian ini yaitu dengan menggunakan triangulasi data, yaitu peneliti mencari alternative lain untuk mencari sumber data, baik itu dengan pengamatan (observasi) secara langsung maupun membandingkan dengan apa yang pernah dikatakan oleh subyek penelitian maupun dokumen-dokumen yang memiliki korelasi dengan informasi tersebut.

\section{HASIL PENELITIAN}

\section{Konsep Dasar Ajaran Agama Islam yang Berkaitan dengan itsar}

Hasil penelitian mengungkapkan bahwa itsar memiliki indikasi perilaku antara lain mengutamakan, mendahulukan atau menghormati orang lain. Seseorang disebut telah berpribadi itsar dalam kehidupan sehari-hari apabila telah mampu memandang kebutuhan dan kepentingan orang lain lebih penting dari pada kepentingan pribadinya sendiri. Jika orang yang lebih mementingkan dirinya sendiri disebut "egois", maka itsar adalah orang yang lebih dulu mementingkan orang lain (dalam urusan muamalah). Itsar mendorong seseorang menjadi pribadi yang mu'tsir, dermawan. Sedangkan egoism diekspresikan melalui perilaku kikir atau bakhil dalam aspek materiil, dan moril. Termasuk didalamnya adalah kesediaan berkorban waktu, tenaga dan psikis.

Seperti yang dikemukakan oleh Islamiyah (2006) bahwa keberagamaan dalam bentuknya yang matang mencakup paling tidak adanya unsur sumber motivasi dan dorongan personal yang sangat kuat dengan jelas mempunyai konsistensi dalam moralitas personal. Dengan kata lain pada pribadi yang matang agamanya terdapat keseimbangan antara dimensi vertical dan dimensi horizontal dalam kehidupan keagamaannya. Terkait dengan hal ini hadis Nabi menyampaikan bahwa yang paling sempurna iman diantara orang-orang mukmin adalah mereka yang paling baik budi pekertinya. Tentu saja budi pekerti dalam arti dan cakupan yang sangat luas. Sementara Al-Qur'an menjelaskan kepribadian seorang muslim yang paling tinggi (muttaqin) ditandai paling tidak tiga hal, yaitu al birru fil aqidah, al birru fil amal, al birru fil khuluq (Q.S Al Baqarah: 17).

\section{Sumber tumbuhnya itsar dalam Diri Manusia}

Dapat dipahami bahwa seseorang baru akan mampu mengutamakan orang lain jika dia telah mampu mengenali dan jujur terhadap dirinya, mampu mengelola kehendak dan motif - motif pribadinya, serta mampu menekan, dan menomorduakan dirinya sendiri. Proses ini, secara psikologis bukanlah suatu proses dan "tahap perjalanan" yang mudah. Oleh karena itu, wajar jika itsar diposisikan sebagai puncak ukhuwah mengingat tindakan mengutamakan orang lain tidak ada landasannya kecuali diawali tumbuhnya perasaan persaudaraan, rasa sepenanggungan dan memerlukan pula landasan empati yang kuat.

Sumber itsar berasal dari dua factor, yaitu internal dan eksternal. Factor internal antara lain; kondisi mental yang sehat dan kematangan beragama yang baik. Karena dari kedua hal tersebut, maka manusia dapat memiliki empati yang baik, percaya diri, bersikap jujur dan menolong orang lain semata-mata karena Allah SWT. Sedangkan factor eksternal adalah lingkungan keluarga dan pendidikan. Hal tersebut akan membuat seseorang memiliki pola perilaku yang terbentuk dari kebiasaan yang budayakan oleh norma keluarga yang suka menolong orang lain. Sikap dermawan juga muncul dari hasil belajar dari lingkungan dan menjadi kebiasaan yang dilakukan.

\section{Konsep dan Komponen itsar}

Hasil penelitian menunjukkan, bahwa subyek penelitian menyatakan bahwa konsep itsar terdiri dari 3 hal, yaitu: a. Lebih mengutamakan manusia daripada diri sendiri, dalam perkara yang tidak bersifat tidak mengganggu agama, menghalangi ibadah dan tidak merugikan waktu; b. Mengutamakan ridho Allah SWT, walaupun dalam keadaan yang 
sulit; c. Ikhlas, karena Allah bukan dari sendiri atupun orang lain.

Menurut Qoyyim (dalam Sholeh, 2011), menempatkan kedermawanan dan itsar ibarat dua sisi kepingan logam, keduanya tidak dapat dipisahkan. Komponen itsar atau dermawan ada 10 jenis, yaitu: a. Kedermawanan dengan pengorbanan jiwa; b. Kedermawanan dengan kekuasaan; c. Kedermawanan dengan kesenangan, ketenangan dan istirahatnya; d. Kedermawanan dengan Ilmu; e. Kedermawanan dengan memanfaatkan kedudukan; f. Kedermawanan dengan Tenaga; g. Kedermawanan dengan kehormatan; h. Kedermawanan dengan kesaaran dan menahan diri; i. Kedermawanan dengan akhlak; dan j. Kedermawanan dengan kepasrahan pada Allah SWT.

\section{Perbedaan Konsep itsar dan Altruisme}

Meskipun secara Bahasa, definisi itsar hamper sama dengan altruis tetapi ada beberapa perbedaan secara konseptual. Menurut Einsberg dan Musen bagaimana dikutip Pujiyanti (2009) hal-hal yang termasuk dalam aspek dari perilaku altruis adalah kepedulian (caring) terhadap sesama, kesediaan berbagi (sharring), kemauan untuk bekerja sama (cooperative), mudah membantu (helping), sudi berderma, bersedekah (donating), satu kata dengan tindakan (honesty) dan kedermawanan, serta memberi tanpa menunggu diminta (generosity). Akan tetapi, dalam penelitian ini, itsar memiliki aspek yang lebih lengkap dengan tidak meninggalkan aspek diatas. Namun konsep yang belum disentuh dalam altruisme adalah jenis kedermawanan, kejujuran, ikhlas dan kesederhanaan (parsimony).

Sikap itsar itu terbagi menjadi 3 jenis: yaitu pertama, jenis terlarang (haram); kedua, dibenci (makruh); dan ketiga adalah diperbolehkan atau dianjurkan (sunnah). Keterangan adalah sebagai berikut, pertama yaitu mendahulukan orang lain pada perkara yang hukumnya wajib bagi manusia untuk menjalankannya secara syariat; Kedua yaitu mendahulukan orang lain pada hal yang dianjurkan oleh agama; Ketiga yaitu mengutamakan orang lain yang berkaitan dengan bukan ibadah, melainkan kegiatan social.

\section{KESIMPULAN}

Berdasarkan hasil analisis yang sudah dilakukan, baik berupa data wawancara dan pembahasan, maka dapat disimpulkan bahwa konsep altruisme dan itsar memiliki perbedaan. Meskipun banyak penelitian yang menggunakan konsep itsar dan altruisme dengan istilah yang sama, namun hasil penelitian ini menyatakan hal yang berbeda. Altruisme adalah Altruism adalah tindakan suka rela yang dilkukan oleh seseorang ataupun kelompok orang untuk menolong orang lain tanpa mengharapkan imbalan apapun, kecuali mungkin perasaan telah melakukan perbuatan baik. Sedangkan itsar adalah sikap dan tingkah laku utama yang mampu dilakukan oleh manusia yang telah mampu dan tidak hanya bersimpati dan berempati terhadap orang lain, tetapi mampu juga berkorban dan memberikan sesuatu yang bernilai bagi orang lain meskipun dirinya juga sedang memerlukan semata-mata hanya karena Allah SWT. Sumber munculnya sikap itsar dapat disimpulkan bahwa berasal dari dua factor, yaitu internal dan eksternal. Factor internal antara lain; kondisi mental yang sehat dan kematangan beragama yang baik. Karena dari kedua hal itu, maka manusia dapat memiliki empati yang baik, percaya diri, bersikap jujur dan menolong orang lain semata-mata karena Allah SWT. Sedangkan factor eksternal adalah lingkungan keluarga dan pendidikan. Hal tersebut akan membuat seseorang memiliki pola perilaku yang terbentuk dari kebiasaan yang budayakan oleh norma keluarga yang suka menolong orang lain.

Sikap dermawan juga muncul dari hasil belajar dari lingkungan dan menjadi kebiasaan yang dilakukan. Dua factor diatas sangat berkaitan satu dengan yang lainnya, dan tidak mungkin bisa terpisahkan sebagai dasar seseorang memiliki itsar. Adapun aspek-aspek dan indikator itsar sebagai acuan dalam penelitian ini selengkapnya adalah sebagai berikut: carring (peduli hak dan kesejahteraan orang lain), sharing (kesediaan berbagi), cooperative (kesediaan bekerja sama) helping (kesediaan menolong), perilaku dermawan (donating \& generosity). kejujuran dalam tingkah laku dan ucapan (honesty), kesederhanaan (parsimony), dan ikhlas tanpa mengharapkan imbalan. 


\section{DAFTAR PUSTAKA}

Gilbert, P., \& Anne, M. C. (2007). Spirituality, values and mental health, jewels for the journey. London and Philadelphia: Jessica Kingsley Publishers

Greenbalt, Igor. (2007). A good samaritan indeed? The quest for-non beneficial altruism in the material worl. Research Seminar. The Open University Of Israel Faculty Of Sosial Sciences. BA Psychology Program, 2007-12-24.

Diunduh Dari Proquest LLM. 26 Januari 2011.

Jaffe, K. (2003). Altruism, altruistic punishment and sosial investment. Acta Biotheoritica Vol.52: P.155-172, 2004.Caracas-Venezuela: Universidad Simon Bolivar, Diunduh dari Proquest LLM.

Kerr, B., Smith, P. G., Feldman, M. W. 2004. What is altruism? Trends in ecology and evolution. Vol. 19 (3). (135-140)

Moroney, M. H. 2014. The Empirical Ties Between Religious Motivation and altruism in Foster Parents: Implications for Faith-Based Initiatives in Foster Care and Adoption. Religions. Vol (5. 720-737)

Piliavin, J. A., Charng, H. W. 1990. Altruism: a review of recent theory and research. Annu. Rev. Social. Vol (16). 27-65

Soroglou, V. 2013. Religion, spirituality and altruism. APA handbook of psychology, religion, and spirituality. Vol (1). 1-19

Thomas, G. (2008). Facilitate first thyself: The person-centered dimension of facilitator education. Journal of Experiential Education. 2008, Volume 31, No. 2. pp. 168-188.

Abubakar, I \& Bamualim, S, S. 2006. Filontropi Islam 7 Keadilan social: studi tentang potensi, tradisi, dan pemanfaatan Filantropi Islam di Indonesia. Jakarta: CSRC UIN Syarif Hidayatullah.

Al-Ghazali. (2001). Bahagia senantiasa: Kimia ruhani untuk kebahagiaan abadi,
(Dedi SR dan Fauzy FB., penterjemah). Jakarta: Pustaka Islam Klasik.

Al Usaimin, Muhammad bin Shalih. (2002). Syarah Riyadhus Shalihin. Kairo:

Darulhaisaini.

Al Syerbini, A.L. (2003). Mu'jam Mushothokhata at Thib An Nafs. Kairo-Mesir:

Pusat Arabisasi Ilmu Pengetahuan.

As Syamali, A. H. (2007). As Sabaqah al Islamiyah (ringkasan kuliah Aidh Al Qarni). Maktabah Syamilah.

Crowford, M.A.A. (2010). The altruistic accountant. CPA Practice Management Forum. Nov.2010. Diunduh Dari Proquest LLM.

Kurzman, C. 2001. Wacana Islam Liberal Pemikiran Islam Kontemporer Tentang Isu-Isu Global. Jakarta: Paramadina Kerja sama yayasan Adikarya IKAPI dan The Ford Foundation

Madjid, N. 1995. Kontekstualisasi Doktrin Islam dalam sejarah. Jakarta: Paramadina

Mubarok, A. (2000). Jiwa dalam Al Quran, Solusi krisis keruhanian manusia modern. Jakarta: Penerbit Paramadina.

Mujib, A. (2006). Kepribadian dalam psikologi Islam. Jakarta: PT. Raja-Grafindo

Persada.

Nasution, S. (2007). Metode Research (Penelitian Ilmiah), cetakan ke-9. Jakarta:

Bumi Aksara

Shadily, H. 1991. Ensiklopedi Indonesia. Jilid 5. Jakarta: PT Ichtiar Baru-van Hoove

Sholeh, Muhammad. 2011. Hubungan AspekAspek Kecerdasan Emosiaonal, itsar dan spiritualitas dengan kepuasan kerja guru. Tesis. UI Jakarta

Sutomo, Imam. 2008. Altruisme dalam kehidupan masyarakat plural (study pemikiran moral Nurcholis Madjid). Disertasi. UII Yogyakarta

Tebba, S. 2004. Orientasi Sufistik Cak Nur: Komitmen Moral Seorang Guru bangsa. Jakarta: Khazanah Populer Paramadina 